\title{
Tingkat Pemanfaatan Sumberdaya Perikanan Pelagis Besar dan Kesejahteraan Rumah Tangga Nelayan di Perairan Kota Jayapura, Provinsi Papua
}

\section{Utilization Level of Big Pelagic Fisheries and Welfare of Fisherman Households in Jayapura City, Papua Province}

Rosmina Sasarari ${ }^{\mathrm{a}}$, Achmad Fahrudin ${ }^{\mathrm{b}}$, Nimmi Zulbainarnic

a Departemen Ekonomi Sumberdaya dan Lingkungan, Fakultas Ekonomi Manajemen, Institut Pertanian Bogor, Jalan Kamper Wing 10 Level 4 Kampus IPB Dramaga, Kota Bogor (16680)

b Departemen Manajemen Sumberdaya Perairan, Fakultas Perikanan dan Ilmu Kelautan, Institut Pertanian Bogor, Kampus IPB Dramaga, Jalan Agatis, Kota Bogor (16680)

c Sekolah Bisnis, Institut Pertanian Bogor, Kampus IPB Gunung Gede, Jalan Raya Pajajaran, Kota Bogor (16151)

\section{Article Info:}

Received: 11 - 04 - 2019

Accepted: 01 - 07 - 2019

\section{Keywords:}

Big pelagic fisheries, bioeconomic multispecies, fisherman welfare, Jayapura City.

Corresponding Author:

Rosmina Sasarari

Departemen Ekonomi

Sumberdaya dan Lingkungan,

Fakultas Ekonomi Manajemen,

Institut Pertanian Bogor, Jalan

Kamper Wing 10 Level 4

Kampus IPB Dramaga, Kota

Bogor (16680);

Email:

rose.sasarari93@gmail.com

\begin{abstract}
The territorial waters of Jayapura City, especially the waters of North Jayapura and South Jayapura are the centers of capture fisheries activities of big pelagic species, namely tuna and skipjack tuna, which need to be utilized to provide welfare for the community, especially fishermen in a sustainable manner. For this reason, this study was conducted to analyze the level of utilization of big pelagic fisheries resources and analyze the welfare level of big pelagic fishermen households in Jayapura city waters. Primary data collection is done through interviews with respondents who are randomly selected. Utilization level analysis was carried out using multispecies bioeconomic analysis and analysis of fisherman welfare levels was carried out using the criteria of the poverty line set by the Central Bureau of Statistics. The results showed the actual utilization rates of tuna and skipjack fisheries resources in the waters of Jayapura City are still in the continuous production of MSY and MEY. Nevertheless, the utilization of these big pelagic fisheries resources needs to be supported by economic institutions that can better distribute their benefits, especially to fishermen. This is because based on the survey conducted; most of the household welfare of the big pelagic fishermen tuna and cakalang in the waters of Jayapura City are still classified as not prosperous.
\end{abstract}

How to cite (CSE Style $8^{\text {th }}$ Edition):

Sasarari R, Fahrudin A, Zulbainarni N. Tingkat pemanfaatan sumberdaya perikanan pelagis besar dan kesejahteraan rumah tangga nelayan di perairan Kota Jayapura, Provinsi Papua. JPSL 9(4): 920-928. http://dx.doi.org/10.29244/jps1.9.4. 920-928.

\section{PENDAHULUAN}

Ketersediaan sumberdaya perikanan di wilayah perairan Indonesia mempunyai nilai ekonomi yang potensial dan menjadi sumber kekuatan ekonomi bagi masyarakat, terutama masyarakat pesisir. Namun demikian, pemanfaatan sumberdaya perikanan tidak hanya berorientasi pada peningkatan produksi dan aspek ekonomi saja tetapi juga berorientasi pada pelestarian sumberdaya perikanan itu sendiri, sehingga dapat ketersediaan sumberdaya dapat tetap ada secara berkelanjutan. Hal ini selaras dengan amanat Undang-Undang Nomor 45 tahun 2009 pasal 6 ayat 1 yang menegaskan bahwa pengelolaan perikanan ditujukan untuk tercapainya manfaat yang optimal dan berkelanjutan, serta terjaminnya kelestarian sumberdaya perikanan (PI 2009). 
Kegiatan perikanan tangkap masih memegang peranan yang sangat strategis dalam pembangunan perikanan di Indonesia dan merupakan salah satu dari keseluruhan potensi perikanan yang memiliki peranan penting dalam perekonomian Indonesia dan bahkan dunia. Hal ini ditunjukkan oleh data produksi perikanan tangkap di Indonesia pada periode 2016-2018 yang cenderung terus meningkat, dengan tingkat pertumbuhan sekitar 4,19\% per tahun (KKP 2018). Sementara di tingkat global, produksi perikanan tangkap sudah cenderung stagnan atau menurun (FAO 2018).

Salah satu komoditas yang memiliki nilai ekonomi tinggi adalah perikanan pelagis besar. Salah satu wilayah yang memiliki ketersediaan sumberdaya ikan pelagis besar adalah perairan di sekitar Kota Jayapura, Provinsi Papua. Saat ini, sumberdaya perikanan pelagis besar di wilayah tersebut dominan dikelola secara tradisional oleh masyarakat setempat guna memenuhi kebutuhan pasar maupun sebagai sumber penghasilan utama dan penghasilan tambahan bagi ekonomi rumah tangga nelayan.

Jenis ikan pelagis besar yang dominan pada wilayah perairan Kota Jayapura adalah ikan tuna (Thunnus albacares), dan ikan cakalang (Katsuwonus pelamis) dengan upaya penangkapan yang dominan dilakukan menggunakan alat tangkap pancing tonda (troll line), dan jaring insang permukaan (surface gillnet). Untuk memenuhi permintaan pasar, nelayan selalu melakukan aktivitas penangkapan secara terus menerus tanpa mengetahui ketersediaan sumberdaya yang tersisa pada perairan sehingga salah satu upaya yang dilakukan untuk membantu nelayan perairan kota Jayapura adalah dengan memberikan informasi pendugaan ketersediaan sumberdaya perikanan pada wilayah penangkapan, dan seberapa jauh tingkat pemanfaatan sumberdaya perikanan dari titik optimal.

Oleh karena itu, diperlukan suatu kajian dan strategi pengelolaan perikanan tangkap sehingga sumberdaya ikan pada wilayah penangkapan Kota Jayapura dapat tetap lestari. Meskipun sumberdaya perikanan merupakan sumberdaya yang dapat pulih, namun keterlibatan setiap pihak dalam pemanfaatan sumberdaya perikanan diperlukan sehingga ketersediaan sumberdaya perikanan dapat tetap terjaga (berkelanjutan). Adapun tujuan dalam penelitian ini adalah menganalisis tingkat pemanfaatan sumberdaya perikanan pelagis besar dan menganalisis tingkat kesejahteraan rumah tangga nelayan pelagis besar di Kota Jayapura.

\section{METODE}

\section{Lokasi dan Waktu Penelitian}

Penelitian dilakukan di wilayah perairan Jayapura Selatan dan Jayapura Utara, Kota Jayapura, yang merupakan pusat aktivitas perikanan tangkap bagi nelayan yang berdomisili di wilayah Kota Jayapura dan berperan sebagai penyedia sumberdaya perikanan laut bagi wilayah Kota Jayapura dan Kabupaten Jayapura. Penelitian dilaksanakan pada bulan Maret hingga bulan Juni 2018.

\section{Metode Pengumpulan Data}

Data primer diperoleh melalui pengamatan langsung dan wawancara dengan rumah tangga nelayan terpilih menggunakan daftar pertanyaan (kuesioner). Sementara data sekunder diperoleh dari dinas teknis terkait sektor perikanan.

\section{Metode Analisis Data}

\section{Analisis Tingkat Pemanfaatan Sumber Data Perikanan Pelagis Besar di Perairan Kota Jayapura}

Tingkat pemanfaatan sumber daya perikanan pelagis besar diperoleh dengan menggunakan analisis bioekonomi 2 (dua) jenis ikan hasil tangkapan Pancing Tonda dan Jaring Insang Permukaan yakni ikan Tuna dan ikan Cakalang.

Nilai parameter biologi terdiri dari intrinsic growth (r), catchability coefficient (q) dan carrying capacity (K). Estimasi parameter biologi multispesies sumberdaya ikan dapat dilakukan dengan beberapa model surplus produksi. Menurut Fauzi (2010) nilai $\alpha$ dan $\beta$ dapat diduga nilainya. Untuk menghindari terjadinya masalah 
"curse of dimensionality" yang berakibat $\mathrm{K}, \mathrm{r}$, dan q tidak dapat diduga maka salah satu nilai harus diduga terlebih dahulu, yaitu parameter q, melalui Algoritma Fox.

Nilai $\alpha$ dan $\beta$ adalah koefisien regresi CPUE dengan effort (E) dan nilai $m=2$ untuk fungsi logistik. Setelah nilai q diduga maka nilai $\mathrm{K}$ dan $\mathrm{r}$ dapat diduga dengan menggunakan rumus:

$$
\begin{aligned}
& \mathrm{K}=\frac{\alpha}{q} \\
& \mathrm{r}=\frac{q^{2}}{K}
\end{aligned}
$$

Alat tangkap ikan yang terdiri atas pancing tonda dan jaring insang permukaan memerlukan standarisasi. Untuk itu, input alat tangkap yang akan distandarisasi merupakan perkalian dari fishing power indeks dengan input (upaya/effort) dari alat yang distandarisasi (Fauzi 2004).

$$
E_{j t}=\psi_{j t} D_{j t}
$$

Dimana,

$$
\psi_{j t}=U_{j t} / U_{s t}
$$

Keterangan:

$\mathrm{E}_{\mathrm{jt}} \quad$ : Effort alat tangkap j yang distandardisasi pada waktu $\mathrm{t}$

$\mathrm{D}_{\mathrm{jt}} \quad$ : Jumlah hari melaut (fishing day) dari alat tangkap j pada waktu $\mathrm{t}$

$\Psi_{\mathrm{jt}} \quad$ : Nilai fishing power dari alat tangkap j pada periode $\mathrm{t}$

$\mathrm{U}_{\mathrm{jt}} \quad$ : Cath per unit effort (CPUE) dari alat tangkap j pada waktu $\mathrm{t}$

$\mathrm{U}_{\mathrm{st}} \quad$ : Cath per unit effort (CPUE) dari alat tangkap yang dijadikan basis standardisasi.

Alat tangkap pancing tonda dan jaring insang permukaan menghasilkan multispesies ikan, sehingga upaya tangkap perlu diproporsionalkan. Proporsi ditentukan berdasarkan jumlah hasil tangkapan atau produksi tiap tahunnya (Zulbainarni 2016). Secara matematis dapat digunakan rumus berikut:

Dimana,

$$
E_{n t}=\frac{h_{n t}}{\sum h_{n t}} \sum E
$$

$\mathrm{E}=\sum E_{n t}$

Ent $=$ proporsi effort spesies ke $\mathrm{n}$ pada tahun $\mathrm{t}$

Hnt $=$ hasil tangkapan spesies ke-n pada tahun $\mathrm{t}$

$\mathrm{n}=$ spesies 1,2

$\mathrm{E}=$ total effort dengan alat tangkap pancing Tonda dan Jaring Insang Permukaan

Selain upaya tangkap, biaya penangkapan juga dihitung secara proporsional dengan rumus (Zulbainarni 2016):

Dimana,

$$
C_{n} \frac{h_{n t}}{\sum_{t=1}^{5} h_{n t}}
$$

$$
C=\sum_{n=1}^{2} C_{n}
$$

Cn adalah proporsi biaya penangkapan spesies ke-n (rupiah), $\mathrm{C}$ adalah total biaya penangkapan (rupiah).

Tingkat upaya tangkap yang dilakukan untuk mencapai hasil tangkapan optimum (MSY) dapat diketahui dengan menyamakan turunan pertama persamaan regresi linear diatas terhadap tingkat upaya tangkap sama dengan nol. Secara matematis ditulis (Fauzi 2010):

$$
h_{n M S Y}=\frac{K_{n} r_{n}}{4}
$$




$$
\begin{gathered}
X_{n M S Y}=\frac{h_{M S Y}}{q E_{M S Y}}=\frac{\left(\frac{r K}{4}\right)}{q\left(\frac{r}{2 q}\right)}=\frac{K_{n}}{2} \\
E_{n M S Y}=\frac{r}{2 q}
\end{gathered}
$$

$\mathrm{E}_{\mathrm{MSY}}$ adalah upaya tangkap lestari, $\mathrm{h}_{\mathrm{MSY}}$ adalah hasil tangkapan lestari, $\mathrm{x}_{\mathrm{MSY}}$ tingkat biomasa pada tingkat MSY.

Fungsi pengelolaam kondisi MEY menurut Zulbainarni (2016) secara matematis dituliskan sebagai berikut:

dengan keuntungan kondisi MEY sebagai berikut:

$$
\begin{gathered}
E_{n M E Y}=\frac{r_{n}}{2 q_{n}}\left(1-\frac{c_{n}}{K_{n} p_{n} q_{n}}\right) \\
x_{n M E Y}=\frac{K_{n}}{2}\left(1+\frac{c_{n}}{K_{n} p_{n} q_{n}}\right) \\
h_{n M E Y}=q_{n} x_{n M E Y} E_{n M E Y}
\end{gathered}
$$

$$
\pi\left(x_{n}, E\right)=\sum p_{n} q_{n} x_{n} E-c E
$$

Tingkat upaya penangkapan pada rezim pengelolaan open access diperoleh pada saat tercapai keseimbangan bioekonomi (rente ekonomi sama dengan nol), secara matematis dapat ditulis:

$$
\begin{gathered}
x_{n O A}=\left(\frac{c_{n}}{p_{n} q_{n}}\right) \\
h_{n O A}=\frac{r_{n} c_{n}}{p_{n} q_{n}}\left(1-\frac{c_{n}}{K_{n} p_{n} q_{n}}\right) \\
E_{n O A}=\frac{h_{n O A}}{q x_{n O A}}
\end{gathered}
$$

Menurut Zulbainarni (2016) terdapat beberapa hubungan timbal balik antar spesies yaitu hubungan kompetisi (competition), hubungan mangsa dan pemangsa (prey-predator) dan hubungan bebas (independent).

Untuk melihat hubungan ketergantungan dan kompetisi antara spesies Tuna dan Cakalang secara matematis sebagai berikut:

Dimana,

$$
\begin{aligned}
& \frac{d x_{1}}{d_{t}}=F\left(x_{1}, x_{2}\right)=r_{1} x_{1}\left(1-\frac{x_{1}}{K}\right)-a x_{1} x_{2} \\
& \frac{d x_{2}}{d_{t}}=G\left(x_{1}, x_{2}\right)=r_{2} x_{2}\left(1-\frac{x_{2}}{K}\right)-b x_{1} x_{2}
\end{aligned}
$$

n : Spesies ke- 1, 2

$\mathrm{x}_{1} \quad$ : Biomas Spesies Tuna

$\mathrm{x}_{2} \quad$ : Biomass Spesies Cakalang

$\mathrm{r}_{\mathrm{n}} \quad$ : Intrinsic Growth Rate Spesies ke-n

$\mathrm{K}_{\mathrm{n}} \quad$ : Carrying Capacity Spesies ke-n

Dimana jika $\mathrm{a}<0$ dan $\mathrm{b}<0$ merupakan model Gause yang menunjukan hubungan saling berkompetisi. Untuk membuktikan hubungan bebas (independent) secara matematis dapat ditulis:

$$
\begin{aligned}
& \frac{d x_{1}}{d_{t}}=F\left(x_{1}, x_{2}\right)-h_{1}(t) \\
& \frac{d x_{1}}{d_{t}}=F\left(x_{1}, x_{2}\right)-h_{2}(t)
\end{aligned}
$$


Apabila nilai koefisien a dan b lebih kecil dari nol maka hubungan ketergantungan antar spesiesnya adalah kompetisi atau satu strata dalam jaring makanan (web food). Apabila nilai koefisien a dan b ada yang negatif dan positif maka hubungan ketergantungan antar spesies adalah predator mangsa.

\section{Analisis Kesejahteraan Rumah Tangga Nelayan Perikanan Pelagis Besar di Perairan Kota Jayapura}

Analisis kesejahteraan rumah tangga nelayan dalam penelitian ini menggunakan kriteria Badan Pusat Statistik (BPS). Berdasarkan indikator yang digunakan oleh BPS (2016), kemiskinan dipandang sebagai ketidakmampuan dari sisi ekonomi untuk memenuhi kebutuhan dasar makanan dan bukan makanan yang diukur dari sisi pengeluaran, sehingga penduduk miskin dapat didefinisikan sebagai penduduk yang memiliki rata-rata pengeluaran perkapita per bulan dibawah garis kemiskinan. Berdasarkan definisi tersebut, maka tingkat kemiskinan rumah tangga dapat diketahui dengan menggunakan rumus sebagai berikut:

$$
\mathrm{GK}=\mathrm{GKM}+\mathrm{GKNM}
$$

Keterangan:

GK = Garis Kemiskinan

GKM = Garis Kemiskinan Makanan

GKNM = Garis Kemiskinan Non Makan

Formula dasar dalam menghitung Garis Kemiskinan Makanan (GKM) adalah :

$$
G K M^{*} j p=\sum_{k=1}^{52} P_{j k p} Q_{j k p}=\sum_{k=1}^{52} V_{j k p}
$$

Selanjutnya GKM tersebut disetarakan dengan 2100 kilokalori dengan mengalikan 2100 terhadap harga implisit rata-rata kalori menurut daerah $\mathrm{j}$, sehingga :

Dimana,

$$
\overline{H K_{j p}}=\frac{\sum_{k=1}^{52} V_{j k p}}{\sum_{k=1}^{52} K_{j k p}}
$$

$K_{j k p} \quad$ : Kalori dari komoditi k di daerah j di provinsi $\mathrm{p}$

$\overline{H K_{j p}} \quad$ : Harga rata-rata kalori di daerah $\mathrm{j}$ di provinsi $\mathrm{p}$

Nilai kebutuhan minimum non makanan secara matematis dapat diformulasikan sebagai berikut :

\section{HASIL DAN PEMBAHASAN}

$$
G K N M_{j p}=\sum_{k=1}^{n} r_{k j} V_{k j p}
$$

\section{Tingkat Pemanfaatan Sumber Data Perikanan Pelagis Besar di Perairan Kota Jayapura}

Nilai estimasi parameter biologi dilakukan melalui regresi model Clark, Yoshimoto dan Pooley (CYP) untuk mendapatkan nilai $\mathrm{r}$ (intrinsic growth rate), q (coefficient cathcability), dan nilai $\mathrm{K}$ (carrying capacity). Nilai parameter biologi secara rinci dapat dilihat pada Tabel 1.

Tabel 1 Nilai parameter biologi multispesies sumber daya perikanan pelagik besar di wilayah perairan Kota Jayapura dengan menggunakan model CYP.

\begin{tabular}{crrr}
\hline Spesies & $\mathrm{r}$ & $\mathrm{q}$ & $\mathrm{K}$ \\
\hline Tuna & 4.93 & 0.000207 & 13.93 \\
Cakalang & 219.79 & 0.00232 & 648 \\
\hline
\end{tabular}

Sumber: Data Sekunder 2018 (diolah) 
Berdasarkan data pada Tabel 1, terlihat bahwa nilai Intrinsic Growth Rate atau tingkat pertumbuhan alami spesies Cakalang lebih tinggi dibandingkan dengan spesies Tuna, hal ini menunjukkan bahwa laju tumbuh spesies Cakalang lebih cepat dibandingkan dengan spesies Tuna sehingga kemungkinan laju tertangkapnya juga lebih tinggi. Nilai koefisien kemampuan tangkap menggambarkan tingkat efisiensi teknis dari penangkapan. Berdasarkan hasil analisis diperoleh nilai koefisien kemampuan tangkap spesies Cakalang lebih tinggi dibandingkan dengan spesies Tuna, dan daya dukung lingkungan spesies Tuna lebih tinggi dari spesies Cakalang.

Dalam upaya tangkap sumberdaya perikanan, biaya penangkapan didefinisikan sebagai biaya variabel yang dikeluarkan per trip melaut diantaranya biaya bahan bakar, biaya bahan pengawet dan biaya konsumsi. Biaya penangkapan rata-rata nelayan dalam penelitian ini yaitu sebesar Rp. 983 125,- per trip.Setelah rata-rata biaya penangkapan diketahui, maka dihitung biaya penangkapan riil series dengan cara CPI atau Indeks Harga Konsumen (IHK) tahun yang akan diketahui dibagi dengan IHK tahun standar, dikalikan dengan biaya nominal pada tahun standar. Biaya penangkapan rill sumberdaya perikanan Tuna dan Cakalang dapat dilihat pada Tabel 2.

Tabel 2 Nilai parameter ekonomi multispesies sumberdaya tuna dan cakalang di Kota Jayapura.

\begin{tabular}{|c|c|c|c|c|}
\hline \multirow[t]{2}{*}{ Tahun } & \multirow[t]{2}{*}{ IHK } & \multirow[t]{2}{*}{ Biaya Rill/Trip } & \multicolumn{2}{|c|}{$\begin{array}{c}\text { Harga Rill } \\
\text { (x Rp 1000/Kg) }\end{array}$} \\
\hline & & & Tuna & Cakalang \\
\hline 2013 & 132.71 & 987834 & 30000 & 20000 \\
\hline 2014 & 143.68 & 1069490 & 30000 & 20000 \\
\hline 2015 & 120.20 & 894715 & 30000 & 25000 \\
\hline 2016 & 123.55 & 919651 & 37000 & 35000 \\
\hline 2017 & 126.12 & 938781 & 50.750 & 39500 \\
\hline
\end{tabular}

Sumber: Data Sekunder 2018 (diolah)

Variabel harga merupakan salah satu faktor yang sangat berpengaruh dalam aspek ekonomi, sehingga harga berpengaruh terhadap jumlah penerimaan yang diperoleh, jika harga jual ikan meningkat maka penerimaan akan bertambah, begitu pula sebaliknya. Harga yang digunakan dalam penelitian ini adalah harga riil yaitu harga nominal dibagi Consumer Price Index (CPI) dikalikan 100.

Berdasarkan Tabel 2, terlihat bahwa harga rill spesies Tuna dan Cakalang per kilogram di Kota Jayapura cenderung meningkat dari tahun ke tahun. Jika dilihat berdasarkan hukum penawaran, harga akan meningkat jika jumlah barang yang ditawarkan berkurang. Namun, perubahan pemanfaatan dan pengolahan sumberdaya perikanan (tradisional) yaitu yang awalnya hanya berupa penjualan ikan dalam bentuk ikan segar dan ikan asap mengalami perubahan menjadi pengolahan tuna loin siap ekspor di wilayah Kota Jayapura menjadi faktor pemicu lainnya dalam meningkatnya harga jual ikan di wilayah Kota Jayapura.

Analisis bioekonomi multispesies dilakukan untuk mengetahui tingkat pamanfaatan maksimum sumberdaya perikanan pelagis besar di perairan Kota Jayapura. Berdasarkan hasil analisis yang dilakukan terhadap spesies Tuna dan Cakalang yang ditanggkap dengan menggunakan alat penangkapan ikan Pancing Tonda dan Jaring Insang Permukaan, maka diperoleh hasil sebagaimana disajikan pada Tabel 3 dan Tabel 4. Pada kedua tabel tersebut, nampak sumberdaya perikanan untuk ikan Tuna dan Cakalang di perairan Kota Jayapura belum mencapai tingkat Overfishing pada level MEY dan produksi sumberdaya perikanan Tuna dan Cakalang dapat ditingkatkan ke level MEY. Kondisi ini disebabkan oleh pemanfaatan sumberdaya perikanan yang masih terbatas dan jumlah stok sumberdaya perikanan yang masih tinggi. Secara grafik produksi lestari dan produksi aktual sumberdaya perikanan Tuna dan Cakalang di perairan Kota Jayapura disajikan pada Gambar 1. 
Tabel 3 Kondisi rezim sumber daya perikanan tuna di wilayah perairan Kota Jayapura.

\begin{tabular}{ccccc}
\hline Rezim & $\mathrm{X}$ & $\mathrm{h}$ & $\mathrm{E}$ & $\begin{array}{c}\text { Rente } \\
\text { (Rp juta) }\end{array}$ \\
\hline MEY & 7.951 & 15.227 & 61.397 & 60468 \\
MSY & 6967 & 15.546 & 71.826 & 276086 \\
OA & 1.969 & 7.366 & 122.794 & 0 \\
Aktual & 11.476 & 9.016 & 24.503 & 186372 \\
MEY & 348 & 3.153 & 19.606 & 45040 \\
MSY & 324 & 3.589 & 7.475 & 35466 \\
OA & 49 & 2.211 & 39.211 & 0 \\
Aktual & 539 & 2.969 & 24.503 & 29969 \\
\hline
\end{tabular}

Sumber: Data Sekunder 2018 (diolah)

Berdasarkan Tabel 3 sumberdaya perikanan untuk ikan Tuna dan Cakalang di perairan Kota Jayapura belum mencapai tingkat Overfishing pada level MEY sehingga produksi sumberdaya perikanan Tuna dan Cakalang perlu ditingkatkan ke level MEY. Kondisi ini disebabkan oleh pemanfaatan sumberdaya perikanan yang masih terbatas dan jumlah stok sumberdaya perikanan yang masih tinggi. Secara grafik produksi lestari dan produksi aktual sumberdaya perikanan Tuna dan Cakalang di Perairan Kota Jayapura sebagai berikut (Gambar 1):

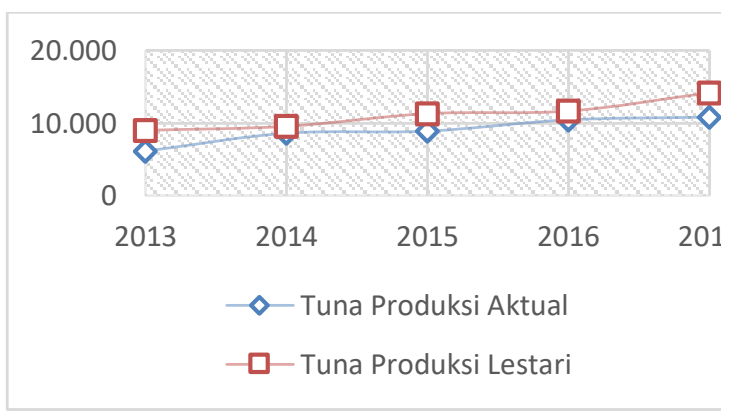

A

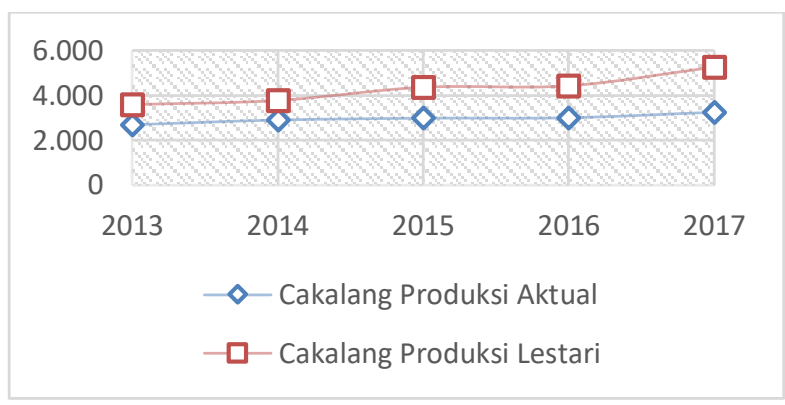

B

Gambar 1 Produksi lestari dan produksi aktual spesies Tuna (A) dan Cakalang (B).

Kedua spesies dalam penelitian ini merupakan spesies yang hidup pada lapisan perairan yang sama yaitu lapisan permukaan sehingga diduga terdapat interaksi antara kedua spesies tersebut. Hasil perhitungan koefisien ketergantungan antar spesies disajikan pada Tabel 4.

Tabel 4 Koefisien ketergantungan antar spesies pelagik besar di perairan Kota Jayapura.

\begin{tabular}{cc}
\hline Spesies & Koefisien Ketergantungan \\
\hline Tuna & -0.00161 \\
Cakalang & -0.00322 \\
\hline
\end{tabular}

Sumber: Statistik Perikanan Tangkap Kota Jayapura, 2017 (diolah)

Berdasarkan Tabel 5, nilai koefisien ketergantungan lebih kecil dari nol yang menunjukkan bahwa spesies Tuna dan Cakalang yang ditangkap dengan alat tangkap Pancing Tonda dan Jaring memiliki hubungan saling berkompetisi. Hal ini dapat terjadi karena kedua spesies hidup pada lapisan perairan yang sama dan memakan jenis makanan yang sama.

Pemanfaatan sumberdaya perikanan diharapkan dapat berperan penting dalam upaya meningkatkan kesejahteraan rumah tangga nelayan. Aktivitas masyarakat nelayan berawal dari persiapan melaut hingga pada 
penjualan hasil tangkapan memiliki berbagai biaya yang rutin dikeluarkan setiap harinya diantaranya biaya bahan bakar dan bahan pengawet (es), selain pengeluaran untuk konsumsi rumah tangga. Berdasarkan data yang dianalisis, maka diperoleh rata-rata pengeluaran pokok pangan dan non pokok pangan rumah tangga nelayan responden pada Tabel 5.

Tabel 5 Rata- rata pengeluaran pokok pangan dan non pokok pangan rumah tangga nelayan di Kota Jayapura (Rp/bulan).

\begin{tabular}{ccc}
\hline Jenis Pengeluaran & Rataan & Simpangan \\
\hline Pokok pangan & 1411656 & 2236875 \\
Non pokok pangan & 312799 & 988883 \\
Total & 32 & 32 \\
\hline
\end{tabular}

Keterangan: responden $(\mathrm{n})=32$

Sumber: Data Primer, 2018 (diolah)

Besarnya pengeluaran per kapita per bulan rumah tangga nelayan cenderung lebih besar dibandingkan rumah tangga pada umumnya hal tersebut dikarenakan besarnya biaya yang harus dikeluarkan oleh nelayan dalam membelanjakan keperluan melaut setiap harinya seperti bahan pengawet (es) dan bahan bakar. Nilai GKM, GKNM dan GK di Kota Jayapura per bulan, masing-masing adalah sebesar Rp 1429105 (GKM), Rp 657424 (GKNM) dan Rp 2086529 (GK).

Jika besarnya pengeluaran rumah tangga nelayan kurang dari nilai garis kemiskinan, maka rumah tangga tersebut dikategorikan sebagai rumah tangga tidak sejahtera. Sebaliknya, jika rumah tangga nelayan memiliki pengeluaran lebih besar dari garis kemiskinan maka rumah tangga tersebut dikelompokan sebagai rumah tangga yang sejahtera. Adapun persentase kesejahteraan rumah tangga nelayan perikanan pelagis besar Kota Jayapura disajikan pada Gambar 2:

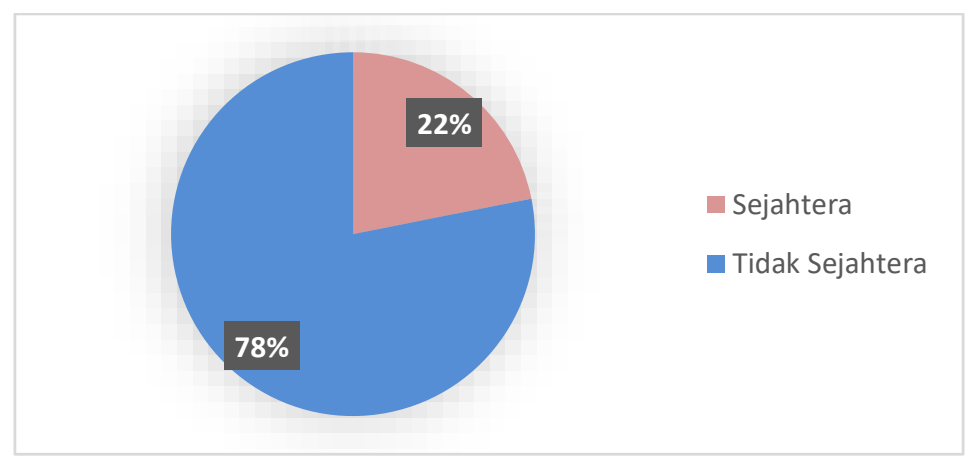

Gambar 2 Persentase kesejahteraan rumah tangga nelayan.

Berdasarkan Gambar 2, diketahui sebanyak 23 atau 72\% rumah tangga nelayan responden di Kota Jayapura tergolong tidak sejahtera, sedangkan sisanya sebanyak 9 atau $28 \%$ tergolong sejahtera.

\section{SIMPULAN}

Kondisi aktual pemanfaatan sumberdaya perikanan Tuna dan Cakalang dengan menggunakan alat penangkapan ikan Pancing Tonda dan Jaring Insang Permukaan di wilayah perairan sekitar Kota Jayapura belum mencapai level MSY dan MEY sehingga masih dapat ditingkatkan ke level MEY sebesar 26651 trip/tahun pada alat penangkapan ikan Pancing Tonda dan sebesar 5.437 trip/tahun pada alat penangkapan ikan Jaring Insang Permukaan. Meskipun demikian, pemanfaatan sumber daya perikanan pelagis besar tersebut perlu didukung dengan kelembagaan ekonomi yang dapat mendistribusikan manfaatnya dengan lebih baik, terutama kepada para nelayan. Hal ini dikarenakan berdasarkan survey yang dilakukan, sebagian besar kesejahteraan rumah tangga nelayan perikanan pelagis besar spesies Tuna dan Cakalang di perairan Kota Jayapura masih tergolong tidak sejahtera. 


\section{DAFTAR PUSTAKA}

[BPS] Badan Pusat Statistik. 2017. Konsep Pengukuran Tingkat Kemiskinan Penduduk. Diakses dari https://www.bps.go.id/ subject/23/kemiskinan-dan-ketimpangan. html pada 4 Maret 2018.

[FAO] Food and Agriculture Organization. 2018. The State of the World Fisheries and Aquaculture 2018: Meeting the sustainable development goals. Rome: FAO. p 3.

Fauzi A. 2004. Ekonomi Sumberdaya Alam dan Lingkungan: Teori dan Aplikasi. Jakarta: PT. Gramedia PustakaUtama. 259 p.

Fauzi A. 2010. Ekonomi Perikanan: Teori Kebijakan dan Pengelolaan. Jakarta: PT Gramedia Pustaka Utama. $236 \mathrm{p}$.

[KKP] Kementerian Kelautan dan Perikanan. 2018. Refleksi 2018 dan Outlook 2019. Jakarta: Kementerian Kelautan dan Perikanan. p 15.

[PI] Pemerintah Indonesia. 2009. Undang-Undang Nomor 45 Tahun 2009 tentang Perubahan Atas UndangUndang Nomor 31 Tahun 2004 tentang Perikanan. Lembaran Negara Republik Indonesia Tahun 2010 Nomor 154, Tambahan Lembaran Negara Republik Indonesia Nomor 5073. Jakarta: Sekretariat Negara.

Zulbainarni N. 2016. Teori dan Praktik Pemodelan Bioekonomi dalam Pengelolaan Perikanan Tangkap. Bogor: IPB Press. 338 p. 